\title{
Piotr Brzezinka „Brzoza” - specjalista w zakresie bronioznawstwa, miner, pirotechniki, oficer Polskiej Policji (28.02.1970 - 02.03.2019)
}

\begin{abstract}
Piotr Brzezinka był najbardziej doświadczonym i najwyżej ocenianym przez specjalistów minerem-pirotechnikiem w naszym kraju. Był też docenianym w kraju i za granicą bronioznawcą. W środowisku minerów-pirotechników nie było osoby, która nie znałaby „Brzozy”, bo taki pseudonim nosił od młodości. Dla wielu był mentorem i nauczycielem, współpracownikiem, przełożonym, dla piszącej te słowa był przyjacielem, wybitnym znawcą i pasjonatem broni, również zabytkowej, zwłaszcza z okresu I i II wojny światowej, chętnie dzielącym się swoją szeroką wiedząi umiejętnościami, zawsze pomocnym w interpretacjach bronioznawczych i w diagnozach badanej sprawy.
\end{abstract}

\section{Oficer Polskiej Policji}

Piotr Brzezinka urodził się 28 lutego 1970 r. w Warszawie. Zarówno prywatnie, jak i zawodowo przez całe życie był związany ze swoim rodzinnym miastem. $Z$ formacjami mundurowymi związał się już w latach dziewięćdziesiątych. Po odbyciu w latach 1990-1992 służby w „Niebieskich Beretach”, czyli Kompanii Rozpoznawczej 7 Batalionu Dowodzenia, 7 Łużyckiej Brygady Obrony Wybrzeża, Gdańsk Wrzeszcz (JW2755) zdecydował się wstąpić w szeregi Policji. Służbę w Policji rozpoczął dnia I kwietnia I993 r. W roku I993, po ukończeniu kursu podstawowego w Ośrodku Szkolenia Komendy Stołecznej Policji w Iwicznej, służył jako policjant Plutonu Pogotowia Policyjnego i Patrolowego Komisariatu Rzecznego Komendy Stołecznej Policji. W tym samym roku ukończył kurs dla ster-motorzystów policji wodnej w Centrum Szkolenia Policji w Legionowie. Rok później ukończył kurs specjalistyczny dla rozpoczynających służbę dochodzeniowo-śledczą w ww. Centrum Szkolenia. Nabyte umiejętności pozwoliły mu i listopada 1995 r. na przejście 
z Plutonu do Zespołu Operacyjno-Dochodzeniowego Komisariatu Rzecznego Policji Komendy Stołecznej Policji, gdzie służył do 31 października 1996 r. Również w tym czasie nastąpił pierwszy kontakt i narodziła się fascynacja Piotra Brzezinki zagadnieniami minersko-pirotechnicznymi, w toku kursu rozpoznania, który ukończył w 1995 r. w Centrum Szkolenia Policji w Legionowie. Po kursie rozpoznania minersko-pirotechnicznego zaczął zdobywać kolejne doświadczenia zawodowe dzięki służbie w Wydziale Kryminalnym I Komisariatu Policji w Warszawie Praga Południe vir Komendy Rejonowej Policji w Warszawie. W listopadzie 1997 r. został wcielony do Mokotowskiej Grupy Antyterrorystycznej („,MOGAT”) zajmującej się zatrzymaniami członków zorganizowanych grup przestępczych. Jednocześnie pogłębiał kompetencje w zakresie nurkowania, by w 1998 r. w Jastarni ukończyć kurs na pierwszy stopień płetwonurkowania.

\section{Pasjonat wiedzy z zakresu minerstwa, pirotechniki i bronioznawca Mistrz samorozwoju i Nauczyciel}

Równolegle ze służbą zawodową w latach 1996-1999 Piotr Brzezinka odbył studia w Wyższej Szkole Policji w Szczytnie, gdzie zdobył tytuł Oficera Dyplomowanego o specjalności Zwalczanie Przestępczości Kryminalnej. Jego praca dyplomowa nosiła tytuł: Jednostki Antyterrorystyczne (Specjalne) Polskiej Policji Iggo-Iggg. Po ukończeniu Wyższej Szkoły Policji w Szczytnie Piotr kontynuował edukację, rozpoczynając w 1999 r. studia magisterskie na Wydziale Prawa i Administracji Uniwersytetu Łódzkiego, które ukończył w 2002 r., uzyskując tytuł magistra po złożeniu pracy pt. Powołanie, organizacja i zadania jednostek antyterrorystycznych Policji - zagadnienia administracyjno-prawne. Odtąd szeroka, często unikatowa wiedza, zarówno merytoryczna, jak i praktyczna, Piotra Brzezinki wielokrotnie wykorzystywana była m.in. w procedowaniu aktów prawnych w Policji. W kwietniu 2000 r. jako oficer Piotr Brzezinka został przeniesiony do dalszego pełnienia służby w Zespole Minersko-Pirotechnicznym Zakładu Szkoleń Specjalnych Centrum Szkolenia Policji w Legionowie. Wówczas też podjął się kolejnych kursów zawodowych, takich jak: szkolenie w ramach doskonalenia zawodowego z zakresu aktywizujących metod nauczania, kurs instruktorów sportu - strzelectwo sportowe oraz kurs doskonalenia zawodowego policjantów Policji Wodnej na stopień bosmana żeglugi śródlądowej.

Ogromny głód wiedzy specjalistycznej, nieprzeciętna inteligencja, pracowitość i systematyczność skłaniały Piotra zarówno do samokształcenia w interesujących go zakresach, jak i do podejmowania i kończenia licznych studiów podyplomowych. W roku 2003 ukończył studia podyplomowe na Wydziale Cybernetyki Wojskowej Akademii Technicznej o specjalności Pedagogika. Jego praca dyplomowa nosiła tytuł: System ksztatcenia ptetwonurków z pododdziatów antyterrorystycznych 
Policji (Brzezinka 2003). W roku $2006 \mathrm{z}$ wyróżnieniem ukończył studia podyplomowe na Wydziale Chemicznym Politechniki Śląskiej o specjalności technologia materiałów wybuchowych, składając pracę pod tytułem Analiza możliwości pozyskiwania materiatów wybuchowych z wyrobów wojskowych pochodzenia wojennego do konstrukcji samodziatowych urzadzeń wybuchowych (Brzezinka 2006). W 201 I r. odbył studia podyplomowe na Wydziale Zarządzania i Dowodzenia Akademii Obrony Narodowej, w specjalności Zarządzanie w organizacjach publicznych, które ukończył pracą dyplomową pt. Dobór kadr na przyktadzie komórek minersko-pirotechnicznych Policji (Brzezinka 20II).

Był w stanie łączyć swe studia i pasje z bardzo odpowiedzialną służbą w Zespole Minersko-Pirotechnicznym Zespołu Szkoleń Specjalnych Centrum Szkolenia Policji w Legionowie, którego od 2004 r. był liderem, z czynnym udziałem w różnego rodzaju zabezpieczeniach policyjnych (m.in. wizyty Papieża Jana Pawła II, Finały Wielkiej Orkiestry Świątecznej Pomocy), czy z pełnieniem funkcji wykładowcy i dla wielu również wzoru i mentora w Centrum Szkolenia Policji w Legionowie.

Przeszło I2 lat pełnienia służby nauczyciela i wykładowcy zaowocowało przeszkoleniem przeszło 2000 słuchaczy, wśród których znaleźli się nie tylko policjanci, ale i saperzy, funkcjonariusze BOR, CBA, PSP, SG, w końcu żołnierze GROM czy żw. Był to efekt przeprowadzenia przez Piotra Brzezinkę ro8 kursów z zakresu rozpoznania minersko-pirotechnicznego. Brał też udział w prowadzeniu I3 kursów z zakresu neutralizacji urządzeń wybuchowych uprawniających do samodzielnego prowadzenia działań minersko-pirotechnicznych, miał czynny wkład w kształceniu około 250 funkcjonariuszy z wymienionych jednostek w ich procesie nabywania uprawnień minera-pirotechnika. Prowadzone przez niego kursy z zakresu śledztwa po wybuchu, które jako wykładowca Centrum Szkolenia Policji w Legionowie przeprowadzil, przyczyniły się do zdobycia uprawnień zawodowych 730 słuchaczy, spośród których 120 było prokuratorami.

Niebywałe zaangażowanie w proces edukacyjny realizowany w Centrum Szkolenia Policji w Legionowie zaowocowało przeprowadzeniem przez Piotra Brzezinkę licznych kursów wysokospecjalistycznych, np. z zakresu neutralizacji ładunków wybuchowych na obszarze wód (dla około 300 słuchaczy), we współpracy ze stoczniami i Marynarką Wojenną. Wart podkreślenia jest fakt, że po zakończeniu przez Piotra Brzezinkę służby w Centrum Szkolenia Policji w Legionowie (w roku 2012) niektóre z prowadzonych przez niego kursów niestety nie były kontynuowane.

Był też wykładowcą na Politechnice Śląskiej w Gliwicach, gdzie uczestniczył w pilotażowym projekcie szkoleniowym przeznaczonym dla menadżerów bezpieczeństwa w zakresie reagowania na zagrożenia czynnikami masowego rażenia, tj. broni chemicznej, biologicznej, radiologicznej i nuklearnej (ang. chemical, biological, radiological, and nuclear - CBRN-E). Zawsze był do dyspozycji swoich 
słuchaczy, o czym przypominał na zakończenie każdego kursu, nigdy nie odmawiał pomocy.

W związku z chęcią rozwoju zawodowego w 20 I2 r. Piotr Brzezinka został przeniesiony do pełnienia służby w Centralnym Biurze Śledczym Komendy Głównej Policji, trafiając do Wydziału do Zwalczania Aktów Terroru. Przeniesienie nie wpłynęło na zakończenie procesu pogłębiania wiedzy specjalistycznej przez Piotra, które choć w nieco ograniczonym zakresie, ze względu na nowe obowiązki służbowe, wciąż kontynuował.

\section{Kierownik Sekcji Minersko-Pirotechnicznej i "cichy bohater"}

W 2015 r. w stopniu podinspektora Piotr Brzezinka objął stanowisko Kierownika Sekcji Minersko-Pirotechnicznej Wydziału Realizacyjnego Komendy Stołecznej Policji. Od tej chwili kierował działaniami minersko-pirotechnicznymi warszawskiej jednostki. Jego wiedza i doświadczenie zawodowe zostały docenione i wykorzystane w momencie powierzenia nowego stanowiska: Zastępcy Dowódcy Samodzielnego Pododdziału Antyterrorystycznego Policji (SPAP) w Warszawie w maju 2017 r. Jako kierownik Sekcji Minersko-Pirotechnicznej Wydziału Realizacyjnego Komendy Stołecznej Policji, Piotr Brzezinka świadom był potrzeb i bolączek, z którymi na co dzień, wraz z policjantami ze SPAP, się mierzył. Przykładowo ubolewał nad tym, że pirotechnicy, od których pracy zależy nierzadko życie wielu osób, nie dysponują sprzętem niezbędnym i najbardziej odpowiednim względem realizowanych zadań (por. Kowalczyk 2019a).

Piotr Brzezinka promował pomysł powstania również w Polce profesjonalnego poligonu pirotechników, na którym znajdowałby się nowoczesny warsztat do neutralizacji urządzeń wybuchowych, analogicznie do tego, co mają do dyspozycji specjaliści w Niemczech i Austrii. Podkreślał też ciągłą potrzebę doskonalenia kadr, postulując np. szkolenia z neutralizacji urządzeń wybuchowych z użyciem technik linowych i śmigłowca oraz z wykonywania prac podwodnych. Twierdzit, że policjanci z komórek minersko-pirotechnicznych oprócz codziennych działań muszą się uczyć i utrwalać zdobyte umiejętności, bo najmniejszy ich błąd może skutkować utratą życia:

Mało się o nich mówi, a przecież wykonują kawał dobrej roboty. Ich praca do najłatwiejszych i najbezpieczniejszych nie należy, ale zamiłowanie do tego, co robią jest silniejsze niż cokolwiek innego. W dużej mierze, to właśnie dzięki nim możemy czuć się bezpiecznie. Mimo, że nazwa na to nie wskazuje, są cichymi bohaterami - cytowano wypowiedź Piotra w okolicznościowym artykule z okazji 25 lat funkcjonowania warszawskich pirotechników (za: Kędzierzawska 2019). 
Jednocześnie Piotr Brzezinka doceniał wszelkie symptomy poprawy status quo w zakresie pirotechniki, jak np. Mobilne Centrum Operatorów Robotów (dalej MCOR), czyli pojazd do wsparcia działań minersko-pirotechnicznych, wyposażony w zestaw specjalistycznych kamer do obserwacji dziennej i nocnej, posiadający stanowiska operatorów robotów, obserwacji i dowodzenia akcją, służący do przewożenia specjalistycznych robotów mobilnych i wyposażenia pirotechnicznego etc., który Komenda Stołeczna Policji otrzymała w 2015 r. do użytkowania od Przemysłowego Instytutu Automatyki i Pomiarów:

MCOR to nasze stanowisko dowodzenia, z którego kierujemy robotami. Przewozimy w nim dużo sprzętu, m.in. stroje anty-odłamkowe, które osłaniają nas przed skutkami wybuchu, a także urządzenia do rozpoznania trudno dostępnych miejsc i materiałów wybuchowych - mówił Piotr Brzezinka (za: Kowalczyk 2orgb).

Nie sposób wymienić wszystkich zagadnień dogłębnie studiowanych przez Piotra Brzezinkę, wszystkich kursów i szkoleń, które ukończył. W zakresie samokształcenia najpełniej angażował się w zgłębianie tajników materiałów pirotechnicznych oraz broni artyleryjskiej i granatów. Jego największą pasją poznawczą były pirotechnika i bronioznawstwo.

\section{Miłośnik dziedzictwa militarnego i student Rzeczoznawstwa uzbrojenia w Instytucie Archeologii Uniwersytetu Łódzkiego}

Lata 2017/20I8 to czas kolejnych studiów podyplomowych Piotra Brzezinki w Instytucie Archeologii, na Wydziale Filozoficzno-Historycznym Uniwersytetu Łódzkiego. Ukończył je, składając doskonałą pracę pt. Polskie konstrukcje granatów ręcznych I9I9-1944 (Brzezinka 2018, zob. Brzezinka w tym tomie). Podkreślał przy tym, że:

W literaturze przedmiotu, nietrudno odnotować, że dotychczas w odniesieniu do charakteryzowanego w pracy okresu, poświęcono nieco uwagi jedynie uzbrojeniu strzeleckiemu, a zwłaszcza polskim konstrukcjom pistoletów i karabinów. Badaniom należy poddać również te element uzbrojenia towarzyszącego żołnierzom w walce, których konstrukcje choć nie były tak skomplikowane jak broni palnej, wymagały wiele pracy i poświęcenia (za: Brzezinka 2018).

Ostatnie ze studiów podyplomowych zaowocowały też nawiązaniem trwałej współpracy w zakresie doradztwa i konsultacji dotyczących zagadnień z domeny archeologii współczesnych konfliktów zbrojnych, w szczególności destruktów broni i amunicji artyleryjskiej. Piotr Brzezinka pełnił rolę specjalisty konsultanta 
w zakresie zagadnień dotyczących destruktów broni i amunicji strzeleckiej i artyleryjskiej w toku realizacji projektu Archeologiczne Przywracanie Pamięci o Wielkiej Wojnie. Materialne pozostatości życia i śmierci w okopach na froncie wschodnim oraz stan przemian krajobrazu pobitewnego w rejonie Rawki i Bzury (I9I4-20I4), przyjętego do finansowania przez Narodowe Centrum Nauki na lata 20I4-2018 (nr projektu NCN - Sonata BIS - nr 2013/Io/E/HS3/00406).

Piotr był inicjatorem i aktywnym uczestnikiem dyskusji na temat tzw. destruktów broni i amunicji, które w jego opinii jako pozbawione cech bojowych winny podlegać procesowi umuzealniania dziedzictwa militarnego. Był też miłośnikiem muzeów wojskowości. Jego ostatnią wizytę w Muzeum Historii Wojskowości w Wiedniu Małżonka Monika wspomina tak:

wielkie muzeum militarne, urządzone w dawnym arsenale. Wspaniałe [...] Piotrek przechadzał się pomiędzy tymi gablotami i pokazywał, co miał w pracy, co sam rozbroił, a za co był zły na saperów w Kazuniu (2. Mazowiecki Pułk Saperów z siedzibą w Kazuniu Nowym), bo coś tam wysadzili, a on nie zdążył im powiedzieć, że to niegroźne i że cenny artefakt kolekcjonerski. Zabytek techniki i sztuki wojennej - bo on tak traktował militaria, które kolekcjonował.

W pośmiertnym wspomnieniu wdowa po młodszym inspektorze Piotrze „Brzozie” Brzezince, Pani Monika Pujdak-Brzezinka wspomina:

Zawsze militaria były grane w pierwszej kolejności [...] pojechaliśmy do Drezna, z dziećmi. Celem był Zwinger i malarstwo Rafaela, ale najpierw musieliśmy pójść do Muzeum Wojskowo-Historycznego Bundeswehry. Muzeum w zasadzie antywojenne. O terrorze, o cierpieniach cywilów, o zwierzętach w służbie. Wspaniałe. Oczywiście wybraliśmy taki dzień, że muzeum było czynne do dwudziestej pierwszej, i wychodziliśmy jako ostatni. Zawsze tak było (za: Puzyńska 2020: 289).

Piotr Brzezinka pasjami zwiedzał muzea poświęcone wojskowości oraz tzw. izby historyczne przy jednostkach minersko-saperskich w Europie. Ubolewał nad tym, że:

Aktualnie, trudno niestety znaleźć w polskich muzeach kolekcje granatów z okresu 1919-1944. Nieliczne pojedyncze egzemplarze są często w złym stanie technicznym, słabo opisane i bez kontekstu historycznego. Dotyczy to także nielicznych zachowanych egzemplarzy pochodzących z czasu produkcji konspiracyjnej. Tę lukę starają się wypełnić prywatni kolekcjonerzy, tworząc namiastki kolekcji i wymieniając się informacjami na forach internetowych. Ich bez wątpienia cenna działalność jest jednak spostrzegana, jako niekoniecznie legalna i stwarzająca zagrożenie. 
Jak zwykle przy tym pełen optymizmu, doceniał również pozytywy:

W tym kontekście należy docenić te nieliczne muzea, w tym prywatne muzea, które tematowi techniki urządzeń wybuchowych (w tym granatów) dedykują sporo uwagi. Do takich muzeów należą między innymi powstałe w 2010 r., na bazie zbiorów specjalistycznej firmy saperskiej Hanny i Piotra Bików Muzeum Saperskie „Explosive” (Dąbrówka koło Wejherowa, woj. pomorskie) oraz powstałe w 2015 r. Muzeum Przemysłu Wojennego w Pogórzu (Skoczów, woj. śląskie). Dzięki takim inicjatywom kiełkuje nadzieja, że historia polskich granatów z lat 1919-1944 przetrwa, a badania nad ich budową i historią produkcji będą kontynuowane i pogłębiane (za: Brzezinka 2018).

Piotr Brzezinka brał również czynny udział w wielu projektach międzynarodowych na terenie Polski, Niemiec i Austrii. Miał wręcz niebotyczną wiedzę historyczną i specjalistyczną, zwłaszcza na temat broni „pochodzenia wojennego”, m.in. granatów z okresu I wojny światowej i kwestii substancji czynnych wykorzystywanych w tzw. artyleryjskiej nawale ogniowej sprzed ponad stu lat. Jako badacz podjął się opisu interpretacji podjętych w toku procesu archeologicznego z pola bitwy w rejonie Bzury i Rawki destruktów broni artyleryjskiej, ze szczególnym uwzględnieniem pozostałości granatów. Jako policjant troszczył się o bezpieczeństwo zespołu badawczego i określanie stopnia destrukcji cech bojowych znalezisk archeologicznych. Niestety, nie zdążył sfinalizować i opublikować wyników tych badań w publikacji stanowiącej podsumowanie Archeologicznego Przywracania Pamięci o Wielkiej Wojnie, do której był zaproszony jako autor opracowania pozostałości po broni i amunicji artyleryjskiej oraz granatów (Archeologiczne przywracanie... 2019).

\section{"Czasy niespokojne, aż trudno sobie wyobrazić co tam u bram św. Piotra się dzieje, skoro Pan Bóg powołuje dziś najlepszego z najlepszych"}

Piotr Brzezinka, cieszący się wielkim autorytetem, szacunkiem i uznaniem, zmarł dnia 2 marca 2019 r. Nagła śmierć Piotra zaskoczyła wszystkich. Pozostawiła w bólu Małżonkę, Córkę Laurę i Syna Emila oraz pozostałych członków Rodziny, przyjaciół, współpracowników, wychowanków, uczniów. Samodzielny Pododdział Antyterrorystyczny Policji w Warszawie okazał się ostatnim miejscem pełnienia służby przez Piotra Brzezinkę. Służbę w Policji pełnił do końca. Wielokrotnie nagradzany za swoją służbę przez Komendanta Głównego Policji, Komendanta Stołecznego Policji, Ministra Spraw Wewnętrznych i Administracji, Prezydenta m.st. Warszawy. Do końca też czynnie angażował się w działania na rzecz pogłębiania wiedzy o broni historycznej i o kontekstach jej użycia. 
Słowa stanowiące podtytuł tej finalnej sekcji wspomnienia o Piotrze oraz te cytowane poniżej, wypowiedział w dniu jego pogrzebu dowódca SPAP w Warszawie kom. Krzysztof Funkiendorf:

\begin{abstract}
Zawsze oddany sprawie, zawsze na posterunku. Cokolwiek by się nie działo, zawsze był do dyspozycji. „Mentor” i „Profesor” - tak go nazywali policjanci, którym przekazywał wiedzę. [...] Całe swoje życie poświęcił pirotechnice. To była jego największa pasja. Wiem, że swoje życie przeżył tak, jak chciał i z pewnością nie zamieniłby go na żadne inne.
\end{abstract}

W trakcie uroczystości pogrzebowych, mówiono: zmart „mentor polskiej pirotechniki”, „niedościgniony wzór do naśladowania”, „mistrz”, „ciągle w biegu, nie zwalniający tempa”, „o kolegach i współpracownikach wypowiadający się tylko w superlatywach”, „kochający mąż i ojciec”, „człowiek będący najlepszą wizytówką SPAP w Warszawie”, „Oficer polskiej policji przez wielkie „O”, „miał ogromny wkład w budowę nowopowstałej służby kontrterrorystycznej”, „wszystko co robił, robił zawsze z misją o bezpieczeństwie społeczeństwa”.

Wspaniały Człowiek, wybitny specjalista w zakresie bronioznawstwa, genialny specjalista w zakresie destruktów broni i amunicji, najlepszy pirotechnik w kraju, oddany, Przyjaciel, dobry, porządny Człowiek, który kochał wiedzę i książki oraz Ludzi - myślano.

W uznaniu dotychczasowych osiągnięć służbowych i blisko 26 lat służby Komendant Główny Policji mianował pośmiertnie podinsp. Piotra Brzezinkę na stopień młodszego inspektora Policji. Natomiast Minister Spraw Wewnętrznych i Administracji odznaczył go złotą odznaką „Zasłużony Policjant”. Piotr Brzezinka był wybitnym specjalistą minerem-pirotechnikiem, był też wielkim pasjonatem $\mathrm{m}$.in. bronioznawstwa i wybitnym specjalistą w zakresie broni „pochodzenia wojennego", dlatego chcieliśmy utrwalić pamięć o Nim i oddać Mu pokłon - chociaż tym drobnym gestem - poprzez niniejszą notę Pro Memoriam, która ukazuje się na łamach czasopisma z zakresu archeologii, w której to dyscyplinie Piotr pokładał znaczne nadzieje w kwestii kształtowania odmiennego od aktualnego stosunku do destruktów broni i amunicji oraz ich wysokiej wartości poznawczej, muzealnej i społecznej. Dawał temu wyraz poprzez czynną współpracę z archeologami i kolekcjonerami, poprzez swoje dążenia do zainicjowania utworzenia „mikro-muzeum pirotechniki przy SPAPie” w Warszawie, oraz poprzez obszerną pracę dyplomową, ostatnią spośród napisanych przez niego prac badawczych, której skrót zamieszczamy w niniejszym tomie (por. Brzezinka 202I).

Za wsparcie przy opracowywaniu tego wspomnienia dziękuję Monice Pujdak-Brzezince oraz Pracownikom SPAP, a także najwspanialszym Kolegom-Studentom ze Studiów Rzeczoznawstwo uzbrojenia na UŁ oraz wykładowcom i opiekunom 
merytorycznym naszych studiów, wśród których był Profesor dr hab. Marian Głosek, któremu dedykowany jest ten tom i któremu gratuluję z serca pięknego jubileuszu.

\section{Bibliografia}

Archeologiczne przywracanie pamięci o Wielkiej Wojnie w rejonie Rawki Bzury (I9I4-I9IS) (2019), A.I.Zalewska (red.), Wydawnictwo IAE PAN, Warszawa.

Brzezinka P. (2003), System kształcenia płetwonurków z pododdziałów antyterrorystycznych Policji (niepublikowany maszynopis).

Brzezinka P. (2006), Analiza możliwości pozyskiwania materiałów wybuchowych z wyrobów wojskowych pochodzenia wojennego do konstrukcji samodziałowych urządzeń wybuchowych (niepublikowany maszynopis).

Brzezinka P. (20II), Dobór kadr na przykładzie komórek minersko-pirotechnicznych Policji (niepublikowany maszynopis).

Brzezinka P. (20I8), Polskie konstrukcje granatów ręcznych 1919-1944 (niepublikowany maszynopis).

Brzezinka P. (2021), Polskie konstrukcje granatów ręcznych IgIg-1944, „Acta Universitatis Lodziensis. Folia Archaeologica", 36, s. 447-466.

Kędzierzawska A. (2019), W sercach naszych trwać będziesz na zawsze, portal: Komenda Stołeczna Policji, http://www.policja.waw.pl/pl/dzialania-policji/ aktualnosci/49373,W-sercach-naszych-trwac-bedziesz-na-zawsze.html [II III 2019].

Kowalczyk A. (2019a), Perfekcyjni i opanowani, „Policja 997”, nr I26/09.2015, http://www.gazeta.policja.pl/997/archiwum-I/2015/numer-126-092015/116635,25-LECIE-MINEROW-PIROTECHNIKOW.html [4 III 2OI9].

Kowalczyk A. (2019b), Elektroniczni partnerzy, „Policja 997”, nr I26/09.2015, http://www.gazeta.policja.pl/997/informacje/I16638,Elektroniczni-partnerzy-nr-126092015.html [4 III 2019].

Puzyńska K. (2020), Monika. Wdowa po mtodszym inspektorze Piotrze „Brzozie” Brzezince, [w:] K. Puzyńska, Policjanci. W boju, Wydawnictwo Pruszyński i spółka, Warszawa, s. 277-348.

Anna Izabella Zalewska

Uniwersytet Marii-Curie Skłodowskiej w Lublinie

Wydział Historii i Archeologii

Instytut Archeologii

e-mail: azalew@op.pl 